\title{
MICROBIALLY PROMOTED SOLUBILIZATION OF STEEL CORROSION PRODUCTS AND FATE OF ASSOCIATED ACTINIDES
}

February 7, 2002

\section{Lead Principal Investigator}

Yuri A. Gorby

Pacific Northwest National Laboratory

P.O. Box 999 Battelle Blvd. MS P7-50

Richland, WA 99352

\author{
509-373-6177 \\ yuri.gorby@pnl.gov
}

\section{Co-Investigators}

Gill G. Geesey

Montana State University

Center for Biofilm Engineering

409 Cobleigh Hall

406-994-4770

Bozeman MT 59717

Frank Caccavo, Jr.

Department of Biology

509-777-4576

Whitworth College

fcaccavo@whitworth.edu

Mail Stop 3902

300 W. Hawthorne Road

Spokane, WA 99251

James K. Fredrickson

Pacific Northwest National Laboratory

P.O. Box 999 Battelle Blvd. MS P7-50

gill_g@erc.montana.edu

Richland, WA 99352

\section{Specific DOE Problems}

DOE needs statements call for "biological and physical chemical parameters for effective decontamination of metal surfaces using environmentally benign aqueous-based biopolymer solutions and microbial processes with potential for decontaminating corroding metal surfaces". Improved understanding of the fundamental processes of microbial reductive dissolution of iron oxide scale on corroding carbon steel will support assessment and potential application of an environmentally-benign and cost effective strategy for in situ decontamination of structural metal surfaces and piping.

\section{Research Objective}

The research is designed to develop a safe and effective biological approach for decontaminating mild and stainless steels that were used in the production, transport, and storage of radioactive materials. 


\section{Research Progress and Implications}

This report summarizes research progress made during the 3-year tenure for this project. An extension with minimal carryover funds was requested and granted to complete and submit manuscripts for publication. During this research, we have:

- Demonstrated that Fe(III)-reducing bacteria reduce $\mathrm{Pu}(\mathrm{IV})$ (insoluble) to $\mathrm{Pu}(\mathrm{III})$ (soluble)

- Confirmed that the bacteria sorb and accumulate trivalent cations, such as $\mathrm{Pu}(\mathrm{III})$.

- Demonstrated that bacteria attached to oxide surfaces are very difficult to remove. Concluded that recovery of bacteria with sorbed $\mathrm{Pu}(\mathrm{III})$ would be impractical.

- Demonstrated that Fe(II) and reduced quinone-like compounds, which are both products of anaerobic respiration, can reduce chemically reduce solid $\mathrm{Pu}(\mathrm{IV})$ to dissolved $\mathrm{Pu}(\mathrm{III})$.

- Conceptualized a bead-based system that effectively removes Pu from iron oxides and accumulates Pu(III) in beads of sodium algintate that can be easily separated from the bulk aqueous phase.

Dissimilatory iron-reducing bacteria enzymatically reduce and dissolve iron oxides, which are common components of corrosion films, and release soluble species of plutonium, $\mathrm{Pu}$ (III). Consistent with our previous hypothesis, cell surfaces sorb Pu(III) and remove it from the bulk aqueous phase. However, we incorrectly hypothesized that bacteria with sorbed actinides could be easily detached and recovered from the surfaces that they had colonized and enzymatically altered. In fact, we have demonstrated that although cells do naturally detach from oxide surfaces during their growth cycle, they leave behind negatively charged reactive portions of their outer surface that are strong sorbants for cations. Without a means for recovering both intact bacteria, their subcellular products and associated contaminants, the use of iron reducing bacteria for decontaminating corroded steel surfaces would not be feasible. Hence, we have targeted an approach that avoids direct contact and attachment of cells to the corrosion films but allows for reduction, dissolution, and sortion of corrosion products and associated actinides.

\section{Description of Bead-Based Treatment}

Iron reducing bacteria are encapsulated in small beads of sodium alginate. Encapsulation prevents direct contact between the bacteria and the contaminated oxide surface. Anthraquinone disulfonate (AQDS) is used as a dissolved electron shuttle to carry electrons from the bacteria to $\mathrm{Fe}(\mathrm{III})$ and $\mathrm{Pu}(\mathrm{IV})$ on the corrosion film. AQDS reduces $\mathrm{Fe}$ (III) to $\mathrm{Fe}$ (II) and $\mathrm{Pu}(\mathrm{IV})$ to $\mathrm{Pu}(\mathrm{III})$. The reduced forms of these metals are very soluble and partition to the aqueous phase. The bacterial surface and the sodium alginate sorb and accumulate $\mathrm{Fe}(\mathrm{II})$ and $\mathrm{Pu}(\mathrm{III})$. The beads, which now contain most of the $\mathrm{Pu}(\mathrm{III})$, can be easily separated from the bulk aqueous phase. The benign process requires no hazardous chemicals or extreme $\mathrm{pH}$ conditions. 


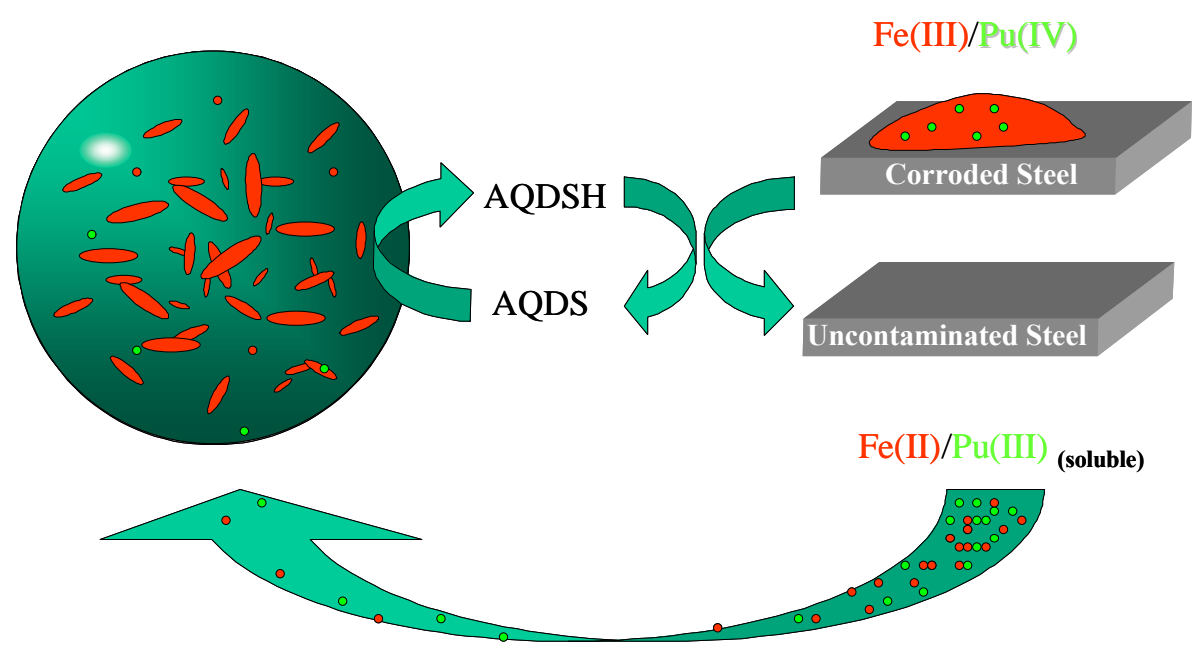

Figure 1. This illustrates a conceptual model of a bead-based system for decontaminating corroded steels. Metal reducing bacteria are enrobed in porous alginate beads. Oxidized anthraquinone disulfonate, AQDS, which will serve as a dissolved electron shuttle between immobilized cells and elements in the corrosion film, diffuses into the beads and is enzymatically reduced by the bacteria. The reduced AQDSH diffuses out of the bead and chemically reduces and dissolves Fe(III) and Pu(IV) in the corrosion film. Soluble $\mathrm{Fe}(\mathrm{II})$ and $\mathrm{Pu}$ (III) sorb to cationic exchange sites within the alginate beads. The beads and accumulated actinides can then be easily separated from the bulk aqueous phase and the uncontaminated steel.

\section{Planned Activities}

The remainder of the project will target the publication of manuscripts that are nearing completion. Additionally, we will examine further the concept and feasibility for using the beadbased approach to remove a range of heavy metals and radionuclides from contaminated iron corrosion films and from contaminated aqueous liquids.

\section{Information Access}

Rai. D, Y.A. Gorby, J. K. Fredrickson, D.A. Moore, and M. Yui. 2002. Reductive Dissolution of $\mathrm{PuO}_{2}(\mathrm{am})$ : The Effect of $\mathrm{Fe}(\mathrm{II})$ and Hydroquinone. J. Sol. Chem. (accepted)

Gorby, Y.A., J. Mclean, A. Dohnalkova, A. Korenevsky, Kevin Rosso, Evgen Vinogradov, and T.J. Beveridge. 2002. Membrane vesicles form the dissimilatory iron reducing bacterium Shewanella putrefaciens strain CN32. FEMS microbial. Lett (in review)

Das, A. and F. Caccavo, Jr. 2001. Adhesion of the dissimilatory Fe(III)-Reducin gbacterium Shewanella alga BrY to crystalline Fe(III) oxides. Curr. Microbiol. 42:151-154

Caccavo, F. and A. Das. 2002. Adhesion of Dissimilatory Fe(III)-Reducing Bacteria to Fe(III) Minerals. Geomicrobiol. J. (accepted)

Das, A. and F. Caccavo, Jr. 2000. Dissimilatory Fe(III) oxide reduction by Shewanella alga BrY requires adhesion. Curr. Microbiol. 40:344-347. 